\title{
Full-length sequence and in vitro expression of rainbow trout estrogen receptor cDNA
}

\author{
Farzad Pakdel ${ }^{1}$, Florence Le Gac ${ }^{2}$, Pascale Le Goff ${ }^{1}$ and Yves Valotaire ${ }^{1}$ \\ ${ }^{\prime}$ Laboratoire de Biologie Moléculaire, U.R.A. 256 C.N.R.S., and ${ }^{2}$ Laboratoire de Physiologie des Poissons, I.N.R.A., \\ Université de Rennes I, Campus de Beaulieu, 35042 Rennes Cedex, France
}

(Received 11 January 1990; accepted 9 April 1990)

Key words: Estradiol; Estrogen receptor; Estrogen receptor cDNA; (Rainbow trout)

\section{Summary}

We previously reported the isolation of a partial cDNA clone encoding the rainbow trout estrogen receptor (rtER). A $0.4 \mathrm{~kb} \mathrm{5'-end} \mathrm{insert} \mathrm{of} \mathrm{this} \mathrm{cDNA} \mathrm{was} \mathrm{used} \mathrm{to} \mathrm{screen} \mathrm{the} \mathrm{trout} \mathrm{liver} \lambda$ gt10 cDNA library, and a full-length cDNA was isolated and sequenced. The principal structural characteristics of the complete coding scquence of the rtER are: first a remarkable homology of the DNA binding (C) and hormone binding (E) domains with those of other species, and second the lack of an A region, the function of which is not yet known but which is well conserved in other species. In vitro expression of the full-length rtER cDNA was carried out after transcription by $T_{7}$ RNA polymerase and translation in rabbit reticulocyte lysate. Translation product analysis shows three major proteins, the largest one of which probably corresponds to the translation of the complete open reading frame of mRNA. The rtER in vitro translation products specifically bind estrogens (estradiol and diethylstilbestrol), without competition from testosterone or cortisol. The equilibrium dissociation constant $\left(K_{\mathrm{d}}\right)$, deduced from the Scatchard plot, is in the same order of magnitude as those determined heretofore in salmon livers during classical experiments. The tissue distribution of rtER mRNA shows that the same mRNA size ( $3.5 \mathrm{~kb})$ is also present in the pituitary and hypothalamus. However, in the pituitary, a smaller sized mRNA (1.4 kb) is also detected.

\section{Introduction}

Estrogen receptors (ER) are part of a large family of receptors which includes steroid and thyroid hormone receptors. Most of these receptors cDNAs have been cloned in different species

Address for correspondence: Y. Valotaire, Université de Rennes I, U.R.A. 256 C.N.R.S., Lab. de Biologie Moléculaire, Campus de Beaulieu, 35042 Rennes Cedex, France.

This work was supported by the Groupement de Coopération Scientifique Bases Biologiques de l'Aquaculture.
(Hollenberg et al., 1985; Green et al., 1986; Jeltsch et al., 1986; Weinberger et al., 1986; Giguere et al., 1987; McDonnell et al., 1987; Privalsky et al., 1988). The family members were recently increased by the cloning of two estrogen receptor-related genes (ERR1 and ERR2), the function of which is not yet known (Chang and Kokontis, 1988; Guiguere et al., 1988). According to structure homology the sequence of these receptors has been divided into six different domains: $A$ to $F$ by Krust et al. (1986). Two of these domains (C and E) seem to have withstood changes during evolution. 
The $\mathrm{C}$ domain is characterized by a high level of basic amino acid residues (lysine-arginine) and by a large number of cysteine residues able to bind $\mathrm{Zn}^{2+}$ and to form loops (7inc fingers), thereby bringing about DNA-binding sites (Maxwell et al., 1987). This structure was first described for the transcriptional factor (TF III A) of the 5 S RNA gene in Xenopus (Miller et al., 1985). More than $50 \%$ of $\mathrm{C}$ domain residues are homologous within the family receptors, and this homology reached 92-100\% among estrogen receptors of various species (Green et al., 1986; Krust et al., 1986; Weiler et al., 1987; Pakdel et al., 1988). The E domain is characterized by hydrophobicity of its amino acid residues and, as far as estrogen receptors of various species are concerned, it remains quite well conserved (60-95\%). However, homology falls to about $17 \%$ when a comparison is made with other kinds of receptors.

These two distinct regions are in fact important functional receptor domains: DNA binding (C) and hormone binding (E) domains. The functions of these domains were inferred from biological activity studies (in vitro binding and gene activation) of protein receptors obtained from cDNA modified through genetic engineering. Expression vectors carrying this modified cDNA were used to transfect various cell types and their receptor activities were tested (Giguere et al., 1986; Kumar et al., 1986, 1987). These experiments showed that the $\mathrm{E}$ domain was requisite and sufficient to maintain hormone binding activity. In addition, it was demonstrated that the construction of active hybrid receptors was possible. For instance, a hybrid receptor construct with a human glucocorticoid receptor ( $\mathrm{C}$ domain) and a human estrogen receptor ( $\mathrm{E}$ region) causes a glucocorticoid-dependent gene to be estrogen sensitive, proving that the two regions are independent (Green and Chambon, 1987). Further analyses showed that 66 amino acids belonging to the $\mathrm{C}$ domain were required to ensure successful receptor binding to DNA. Moreover, 40 amino acids from the $D$ region (hinge between $\mathrm{C}$ and $\mathrm{E}$ ) play an important role in the overall process (Kumar et al., 1986, 1987).

As regards fish species, knowledge of ER gene expression regulation is solely based on studies of labeled estrogen binding. By means of such methodology, ER were identified in rainbow trout
(Maitre et al., 1985) and atlantic salmon (Lazier et al., 1985) livers, which both have a similar dissociation constant $(2-4 \mathrm{nM})$.

We previously described the cloning and partial sequencing of the rainbow trout estrogen receptor (rtER) (Pakdel et al., 1988). This partial cDNA sequence, which encompasses most of the coding region, showed two domains featuring remarkable amino acid homology with human, chicken and Xenopus estrogen receptors. Therefore, the difference observed in rtER mRNA sizes and those of other species is due to the $3^{\prime}$-untranslated region of the messenger. At this point, we report complete nucleotide and predicted amino acid sequence of the rainbow trout estrogen receptor. The sequence reveals some structural features which are different from the other species. We also describe the use of the $T_{7}$ transcription vector system to generate analytical amounts of fulllength protein and demonstrate that the cell-free translated protein possesses estrogen binding properties analogous to those of the native receptor. Finally, the rtER mRNA was detected in several rainbow trout organs.

\section{Materials and methods}

\section{Materials}

$\left[2,4,6,7-{ }^{3} \mathrm{H}\right]$ estradiol $(99 \mathrm{Ci} / \mathrm{mmol})$, estradiol-6(O-carboxymethyl)-oximino-(2-[ ${ }^{125}$ I]iodohistamine) $(2090 \mathrm{Ci} / \mathrm{mmol}),\left[\alpha-{ }^{32} \mathrm{P}\right] \mathrm{dCTP}(800 \mathrm{Ci} / \mathrm{mmol})$, $\left[{ }^{35} \mathrm{~S}\right]$ thio-dATP $(600 \mathrm{Ci} / \mathrm{mmol})$ and membranes (Hybond-N) were obtained from Amersham France. L- $\left[{ }^{35} \mathrm{~S}\right]$ methionine $(1100 \mathrm{Ci} / \mathrm{mmol})$ was purchased from New England Nuclear. The $\mathrm{m}^{7} \mathrm{GpppG}$, the random primer labeling kit, the exonuclease III and the Mung bean nuclease were from Boehringer Mannheim France. Placenta RNasin, RQ1 DNase, $T_{7}$ RNA polymerase, reticulocyte lysate and ribonucleosides triphosphate were obtained from Promega Biotec. The guanylyltransferase was obtained from Gibco B.R.L. The plasmide Bluescript $\mathrm{KS}+/-$ was from Genofit. The oligo(dT)-trisacryl $M$ was obtained from I.B.F. The sequenase kit was obtained from U.S.B. Restriction enzymes were obtained from Gibco B.R.L. or Boehringer Mannheim France. All other chemicals were purchased from Sigma and Merck. 
Isolation and sequencing of a full-length rtER $c D N A$ clone

The female trout liver cDNA $\lambda$ gt10 library (Pakdel et al., 1988) was plated onto Escherichia coli hfl, with $-10^{4}$ phages $/ 8.5 \mathrm{~cm}$ diameter Petri dish.

Duplicate filters (Hybond-N) were screened with a 400 bp ${ }^{32} \mathrm{P}$-labeled 5 '-end fragment, specific to the rtER cDNA previously described (Pakdel et al., 1988). Seventy-five positive clones were isolated from $5 \times 10^{5}$ phages. One clone containing a 3270 bp insert was purified and sequenced on both strands with the dideoxy chain termination method of Sanger et al. (1977).

\section{In vitro transcription, translation and hormone bind-} ing

The complete rtER cDNA ( $3270 \mathrm{bp}$ ) was subcloned in the $5^{\prime}$ to $3^{\prime}$ orientation in the EcoRI site of the plasmid Bluescript $\mathrm{KS}+/$ - expression vector, downstream from the $T_{7}$ RNA polymerase promoter. The DNA template was linearized with $X h o I$ which cleaves the plasmid down-stream from the poly dA-dT of the insert, and then transcribed with $\mathrm{T}_{7}$ RNA polymerase (Krieg and Melton, 1984). The capping reactions were carried out according to Contreras et al. (1982) and Krieg and Melton (1984).

The in vitro translation reactions were performed using various amounts of in vitro $T_{7}$ RNA polymerase transcript (according to the text) in a rabbit reticulocyte lysate (methionine depleted) with $40 \mu \mathrm{M}$ unlabeled methionine or $20 \mu \mathrm{Ci}$ of $\mathrm{L}-\left[{ }^{35} \mathrm{~S}\right]$ methionine, at $30^{\circ} \mathrm{C}$ for $60-90 \mathrm{~min}$ in a final volume of $50 \mu 1$. Reactions were performed as recommended by the supplier (Promega Biotec). Translation products of synthetic mRNA were analyzed by sodium dodecyl sulfate-polyacrylamide gel electrophoresis (SDS-PAGE) according to Laemmli (1970).

Estradiol binding to in vitro translation products was determined through incubation of 20-25 $\mu 1$ of an in vitro translation mixture with $6 \mathrm{nM}$ $\left[{ }^{3} \mathrm{H}\right]$ estradiol or with various concentrations of [ ${ }^{125} \mathrm{I}$ ] estradiol at $2^{\circ} \mathrm{C}$ for $12 \mathrm{~h}$ in the presence or absence of a 100 -fold unlabeled steroid competitor (estradiol, diethylstilbestrol, cortisol and testosterone) in a $100 \mu$ l binding buffer containing $10 \mathrm{mM}$ Tris- $\mathrm{HCl} \mathrm{pH}$ 7.9, $1.5 \mathrm{mM}$ EDTA, $10 \mathrm{mM}$ sodium molybdate, $10 \mathrm{mM}$ monothioglycerol and $10 \%$ glycerol. Unbound steroids were separated by means of two successive treatments with $1 \%$ dextran-coated charcoal.

\section{Northern hybridization analysis}

Total RNA was extracted from different tissues of adult male or female trouts, through modification of the Auffray and Rougeon technique (Auffrey and Rougeon, 1980). The poly (A) ${ }^{+}$RNAs were obtained after chromatography of the total RNA on oligo(dT)-trisacryl $M$, and were separated on $1 \%$ agarose gel containing formaldehyde, transferred to a nylon membrane (Hybond$\mathrm{N}$ ), and hybridized with ${ }^{32} \mathrm{P}$-labeled complete rtER cDNA under Thomas's conditions (1980).
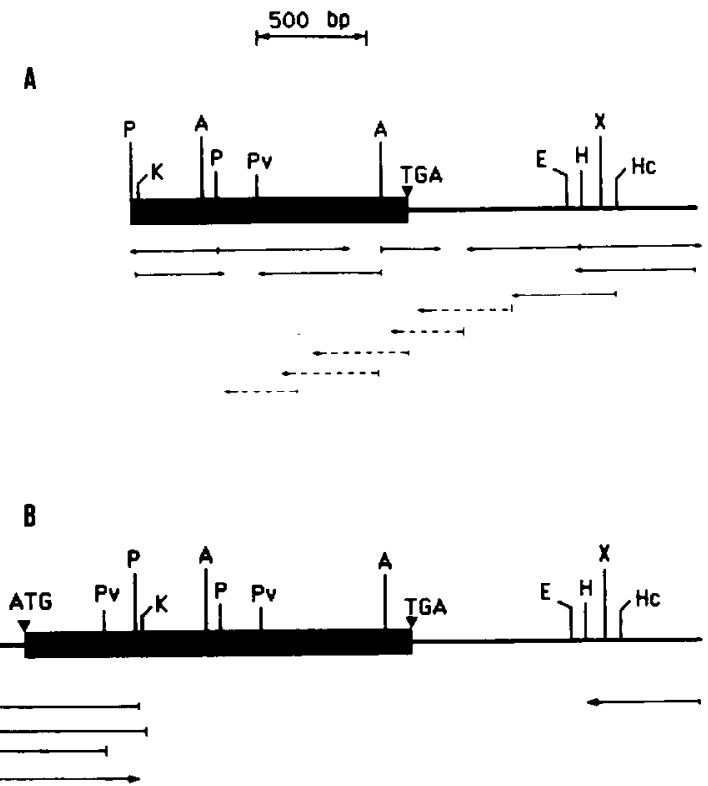

Fig. 1. Restriction endonuclease map and sequencing strategy of the cDNA corresponding to rtER mRNA. The thin lines represent the $5^{\prime}$ and $3^{\prime}$ untranslated regions and the black box corresponding to coding region of mRNA. The main restriction sites are: A, ApaI; E, EcoRI; H,HindlII; Hc, HincII; K, KpnI; P, PstI; Pv, PvuII; X, XbaI. Restriction fragments were sequenced by the dideoxy-chain termination method (Sanger et al., 1977) in the direction shown by the arrows. The restriction fragments shown by dashed arrows were obtained by unidirectional deletions with exonuclease III according to the method described by Henikoff (Hillier et al., 1989). $A$ : Schematic representation of the cDNA clone $(2602 \mathrm{bp})$ resulting from the partial sequence rtER mRNA (Pakdel et al., 1988). $B$ : Schematic representation of the cDNA clone $(3270$ bp) resulting from the complete sequence rtER mRNA. 


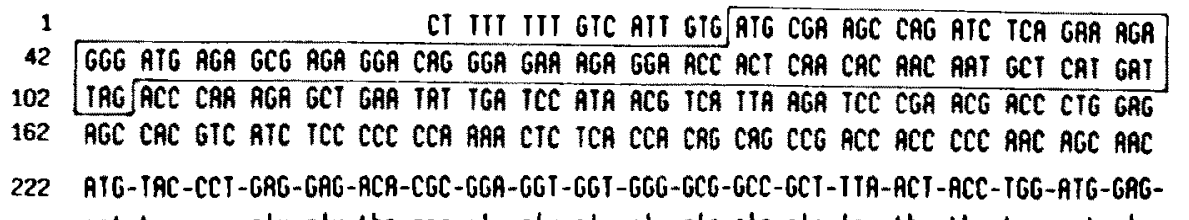
net-tyr-pro-glu-glu-thr-org-gly-gly-gly-gly-ola-alo-olo-leu-thr-thr-trp-aet-glu- 20 gly-aet-thr-thr-g/n-pro-leu-pro-lyg-olo-org-pro-leu-ser-lle-thr-pro-pro-pro-pro-

AGG-ATG-CCC-ACG-GRC-CCT-TCG-GAT-GCC-AGC-ATG-CAG-TCC-CTG-GCC-AGC-AGT-CCC-ACC-GCCorg-ect-pro-thr-asp-pro-ser-osp-gly-ser-ect-gln-ser-leu-gly-ser-ser-pro-thr-gly- $\quad \infty 0$

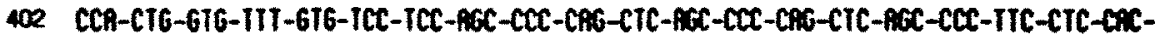
pro-lou-vol-phe-val-ser-ser-ser-pro-gln-leu-ser-pro-gln-leu-ser-pro-pho-lou-hls- 80

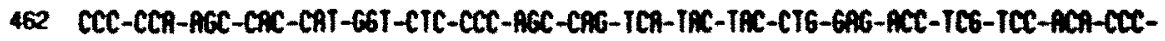
pro-pro-ser-hls-hls-gly-leu-pro-ser-gln-ser-ty-ty-leu-glu-thr-ser-ser-thr-pro- 100

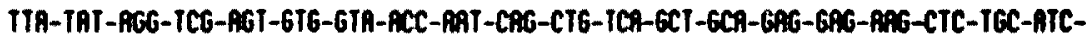
lou-ty-org-sor-ser-val-vol-thr-asn-g|n-leu-sar-olo-olo-glu-glu-lyo-leu-cyo-1lo- 120

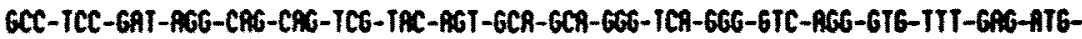
olo-ser-osp-org-gln-gln-ser-tyr-ser-olo-olo-gly-sor-gly-vol-org-val-phe-glu-cot- 140

642 GCC-AAC-GAG-ACG-BGG-TAC-TGT-GCG-6TC-TGC-AGC-GAC-TIT-GCC-TCT-GG6-TAC-CAC-TAC-6GAala-asn-glu-thr-arg-ly-cys-alo-val-cys-ser-asp-pho-ala-sor-gly-tyr-hls-tyr-gly- 160

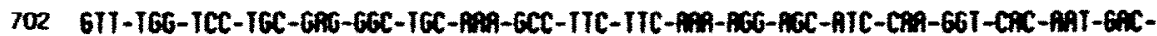
vol-trp-ser-cys-glu-gly-cys-lys-ale-phe-phe-lys-org-ser-|lle-g|n-gly-hls-asn-osp- 160

762 TAC-ATG-TGC-CCT-GCG-ACT-AAC-CAG-TGT-ACA-ATG-GAC-BGG-AAT-CGT-AGG-AAG-AGC-TGC-CAGtyr-oet-cys-pro-alo-thr-osn-gln-cys-thr-eot-osp-org-osn-org-arg-lys-sor-cys-gln- 200

822 GCA-TGC-CGC-CTC-AGA-ARG-TGT-TAT-GRA-GTG-GGG-ATG-GTG-ARA-GGA-GOC-ITG-CGT-ARG-6ACala-cys-arg-leu-arg-lys-cys-tyr-glu-wol-gly-act-wal-lys-gly-gly-leu-arg-lys-osp- 220

C6C-66T-666-CGG-6IT-CTC-AGG-RAG-GAT-ARG-CGG-TAT-1GT-GCC-CCT-CCT-66T-GAC-AGA-6AGorg-gly-gly-arg-val-lou-org-lys-osp-lys-org-ly-cys-gly-pra-olo-gly-osp-org-glu-240

AAA-CCT-ACG-GTG-ACC-TGG-AGC-ACA-GCA-CAG-CEC-CCT-CAG-GAC-GGG-GGT-AGG-AAC-AGC-AGClys-pro-thr-val-thr-trp-ser-thr-gly-gln-org-oro-gln-osp-gly-gly-org-osn-ser-ser- 260

1002 AGC-AGT-CTC-ABT-GGT-GGT-GGA-GGA-TOS-CGT-6GG-CCC-PGR-ATC-ACC-ATG-CCT-CCT-GAA-CAGser-ser-leu-asn-gly-gly-gly-gly-trp-org-gly-pro-org-|le-thr-aet-pro-pro-glu-gln- 280

1062 GTG-CTG-ITC-ETG-CTG-CAG-GGG-CAG-ACT-CCG-GCC-CTG-IGT-TCT-CGT-CAG-ARG-GTG-GCC-CGCvol-leu-phe-lou-leu-gln-gly-gln-thr-pro-alo-leu-cys-ser-arg-gln-lyg-vol-olo-org- 300

1122 CCC-IAC-ACB-GAG-GIC-ACC-ATG-AIG-ACC-CIG-CIC-ACC-AGC-ATG-GCT-GAC-ARG-GAG-CIG-GTGpro-tyr-thr-glu-val-thr-aet-net-thr-leu-leu-thr-ser-oet-ala-osp-|ys-glu-leu-val- 320

1182 CAC-ATG-ATC-GCT-TGG-GCT-AAG-ARA-GTA-CCA-GGT-TIC-CAG-GAG-CTG-ICT-CTC-CAT-GRC-CAGhis-net-ile-ala-trp-alo-lys-lys-val-pro-gly-phe-gln-glu-leu-ser-leu-his-osp-gln-340

Fig. 2. Complete nucleotide sequence and deduced amino acid sequence of the rtER cDNA. The numbers on the left refer to the position of the nucleotides and those on the right to that of the amino acids in the long open reading frame (574 residues). In the 5 '-untranslated region, a short open reading frame ( 28 amino acids) is boxed. The initiation ATG codon and the polyadenylation signal (AATAAA) are underlined. The stop triplet TGA is indicated by asterisks and the CATTG sequence $10 \mathrm{bp}$ upstream from the 
1242 GTG-CAG-CTG-CTG-GAG-AGT-TCC-TGG-CTG-GAG-GTG-CTG-ATG-ATC-GGA-CTC-ATR-TGG-CEG-ICC-

vol-gln-leu-leu-glu-ser-ser-trp-leu-glu-val-leu-eet-lle-gly-leu-lle-lrp-org-sor- 360

1302 ATC-CAC-TCC-CCT-GGG-APA-CTC-ATC-ITC-GCC-CAG-6AC-CTC-ATA-CTG-GAC-AGG-AGT-GAP-GC6-

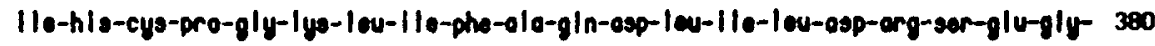

1362 6PC-TGT-GT6-GAG-GGT-AT6-GCT-GAG-ATC-TTC-GRC-RT6-CTC-CT6-CCC-RCT-6TG-TCT-CEC-ITCosp-cys-val-glu-gly-sel-olo-glu-ile-phe-osp-sol-lou-leu-ala-thr-wal-ser-arg-pho- 400

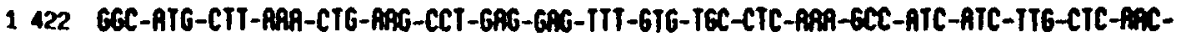
gly-oet-leu-lyg-leu-lys-pro-glu-glu-phe-wol-cyo-lou-lys-ala-lle-1le-lou-lou-asn- 420

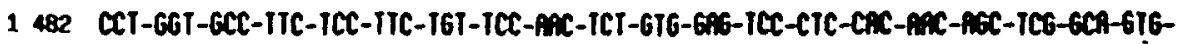
pro-gly-ala-pho-sor-pho-cys-sor-asn-sor-wol-glu-sor-lou-hlz-osn-oer-sor-alo-wol- 40

1542 6AP-AGC-ATG-CTG-GAC-AMC-ATC-ACC-GAC-6CC-CTC-ATC-CAC-CAC-ATC-ACC-CAT-ICA-6GR-GCCglu-ser-set-lou-0sp-0sn-i le-thr-osp-alo-leu-ile-his-his-ile-ser-his-sor-gly-olo- 460

1 GO2 TCT-GTG-CAG-CAG-CPG-CCC-AGA-CGG-CPO-GCC-CAG-CTC-CT6-CTC-CTG-CTC-TCA-CAC-ATC-AGAsor-vol-gln-gln-g|n-pro-org-org-gln-alo-gln-lou-lou-lou-lou-lou-sor-hls-llo-org- 480

1662 CRT-RTG-AGC-BAC-ARA-GGC-RTG-GAG-CAC-CTT-TAC-ACC-ATA-ARA-TGT-ARG-ARC-ARA-GT6-CCThis-oel-sor-osn-lys-gly-oet-glu-hl s-lou-tyr-sor-i lo-lys-cys-lys-osn-lys-wol-pro- 500

1722 CIG-TAC-GAC-CTG-CTC-CTG-GAG-ATG-CTG-GAC-GGT-CAC-CGE-CTC-CAR-GCC-CCA-GGC-PAPA-GTGlou-tyr-osp-lou-leu-leu-glu-set-leu-osp-gly-hig-org-lou-gln-olo-pro-gly-lyg-wal- 520

1782 GCC-CAR-GCT-GGG-GAR-CAG-ACC-GAG-GCC-CCC-TCT-ACC-ACC-ACT-ACC-ACC-TCC-ACR-6GC-TCCola-gln-olo-gly-glu-gln-thr-glu-gly-pro-ser-thr-thr-thr-thr-thr-ser-thr-gly-sor- 540

1842 AGC-ATA-GGG-CCG-ATG-CGA-GGC-AGC-CAG-GAT-ACC-CAC-ATC-AGA-ACC-CCT-GGT-TCC-GGG-6TAser-i le-gly-pro-net-org-gly-ser-gln-osp-thr-hig-ile-org-ser-pro-gly-ser-gly-wal - 560

1902 CTC-CAG-TAT-GGC-TCC-CCC-AGC-TCA-GAC-CRO-ATG-CCC-AIT-CCG-TGA GATACAGARA TRGGTATITG lou-gin-t gr-gly-ser-pro-ser-ser-osp-gln-oet-pro-lle-pro ***

1967 TRGATACGGA AGATGTARAA GTCCTATTTA CATGCAGTAT GTATAGAGAG AGATATTTTG 2027 ARATGTRTGG ACTRAGAATG GATAARAAAT ATGCRATTTA TTRATGTGCA IRTTCATTAC 2087 ITAITTGITI GTARTTGAAG TGATTCAITI GCAAITIGAT RGATAGTCAR RAITAAIITA 2147 AGCAGCAATC CTATTARRCA TITAGRAATG ITCACATTIT GTACTGGTAC ACAACGGACT 2207 GARATGTACT CAGTCACACC AGGGAGTGAT ICACCTAAGG RACCAAAAGG ARGCARACCA 226? AATGAAACGG GGAGGGACTA GTACCTRTAT ITGTCCARTA GARACACATT TTCGTTGCCT 2327 TTCACCATGT TIGCACTITT GAGICGATIC ICITTCIGTG GCITGACAAC AGITCACCGT 2387 TCTGCGCTTG CACCARGTAT TIAGCCATTG TGTGGRGCAC TGTTAGCAGC AGAGTCATGT 2447 GATAGAGCAG CTAGTCTATG TAGATCAATG CTITATAACC TGTGTGGACA CARGCTGTGC 2507 CCTIGACCAR AGTGCACTTC ICCAGGTGAG GGAAATGTGG GCAITGTATA CCTITIGTAG 2567 CTTARCATTG ATGACTGCTT GTCATATTAT TCTGAGACGG ATGTAATTCA AAACATTGAT 2627 ATATACTIIT TTATGTIATG GCTACARATT CAAATATTCT GATATCAGGT GCCTTGTTTA 268? GAAARTGTRA IIGIITAAAT GTATCAAITI ACAAGCAGCC AACATTTCTG ARGCTTGAAT 2747 GTTCTGAGCC GTTCTAGCAA AGTGTTTGAA GATATTTAAR RACAAATGRC ARATGTGATG 2007 TAITICTGTI AATGTATIAC TGCAIIITGI TCTAGRGTAA ATATGITCAT AATCTATGIT 2867 GTGCAGAACA CTTCACAGCA ITTCAGTTGA CTGACAACAT ATATGTTATC GACATTGTAT 2927 ATGATTARAA ACAGAAGTAR ARTATTGGCC TCRAGTARTT TAGCCTITTC TGTCGCTGTT 2987 ATGTGGATAT TTCTATGCIT ACTTGAACAG ATTGATGTTC AITTAATGTA ATTGTATAAT 304? GTGAGTGTAR GGTAGACATC TGGAGATGAT CAARCGCATT GCTCCTTCAT TTGTTCTACC 3107 GTRTGAGCGC CACTGCTGAT GRATCAGTCT GCTCTACAGT AGTATACACA CACCACACTG 3167 TACAGGTGAT GTATGTGATT AATGTTCATG CACAGCCCAC AITICAACTO ACTITCATGT 3227 ACCATGÇAI! GCTGTGRATA RAGARATTGA RCCCAAARAA AAAG

Fig. 2 (continued). 


\section{Results}

\section{Isolation and sequencing of $a$ full-length $r t E R \quad c D N A$}

We previously reported the isolation of a partial cDNA clone encoding the rtER and defined the main domains of biological activity (Pakdel et al., 1988). In order to obtain the sequence of the complete rtER cDNA, a $0.4 \mathrm{~kb}$ insert corresponding to the $5^{\prime}$ end of the partial rtER CDNA was used to screen the $\lambda$ gt 10 cDNA library. 75 positive clones were isolated and several of them, whose length was compatible with that of the more abundant mRNA, were studied. Fig. 1 shows the restriction maps of the partial and complete rtER cDNA and the strategy used to sequence them by means of the M13 dideoxy chain termination method (Sanger et al., 1977). The restriction maps show that the $3^{\prime}$ ends of these two clones are identical (sequencing reveals that the only difference is two additive $A$ residues in the poly $A$ tail) and that the full length is characterized by a longer $5^{\prime}$ end.

The complete cDNA sequence together with the deduced amino acid sequence of the receptor protein is shown in Fig. 2. Sequence analysis shows an open reading frame, starting at the ATG codon

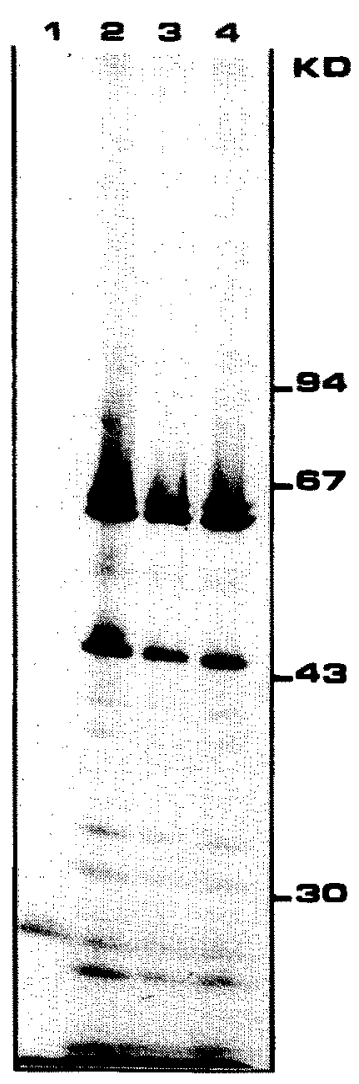

A

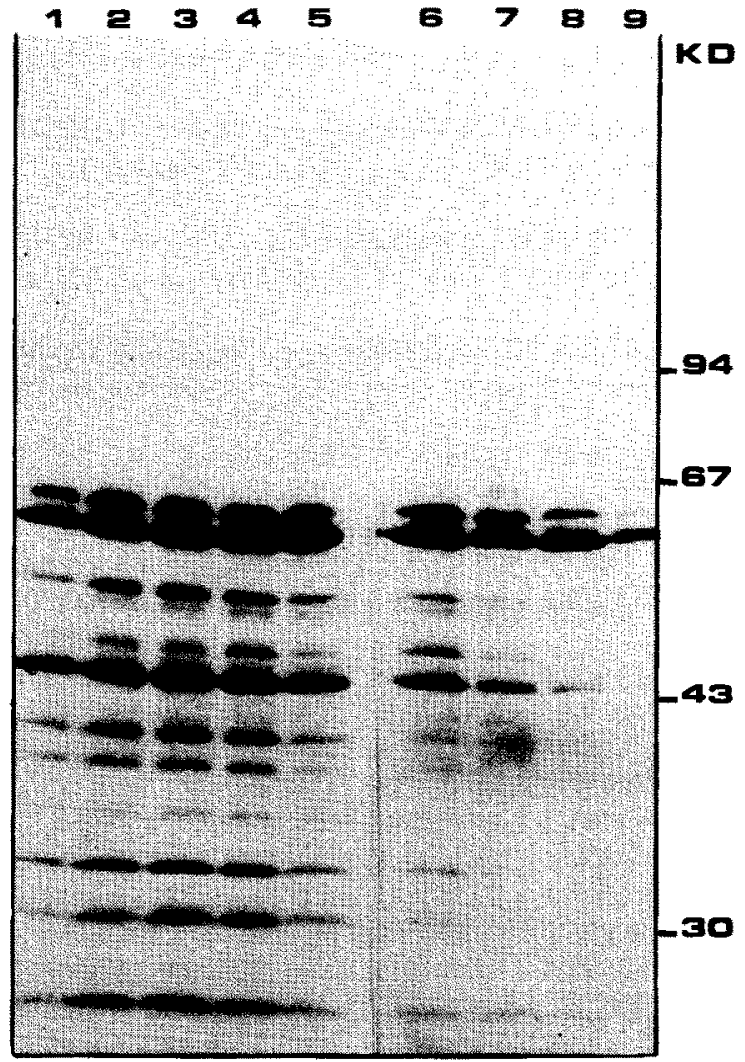

B

Fig. 3. In vitro translation products encoded by complete rtER mRNA analysis. $A: 2 \mu \mathrm{g}$ of in vitro synthesized mRNA with or without a $5^{\prime}$ cap were translated in rabbit reticulocyte lysate (final volume $50 \mu 1$ ) in the presence of [ ${ }^{35}$ S]methionine. $10 \mu l$ of the in vitro translation mix were electrophoresed on a 10\% SDS-polyacrylamide gel. Lane 1, control lysate (without mRNA); lane 2, translation products of the uncapped mRNA; lane 3, translation products of the capped mRNA according to the Krieg and Melton method (1984); lane 4, translation products of the capped mRNA according to the Contreras et al. (1982) method. B: Various concentrations of uncapped rtER mRNA were translated in rabbit reticulocyte lysate in the presence of $\left[{ }^{35}\right.$ S|methionine. Equal volumes of each assay were analyzed through $10 \%$ SDS-PAGE. The concentrations of rtER mRNA are: lane $1,40 \mu \mathrm{g} / \mathrm{ml} ; \mathrm{lane} 2,20$ $\mu \mathrm{g} / \mathrm{ml}$; lane 3, $10 \mu \mathrm{g} / \mathrm{ml}$; lane $4,5 \mu \mathrm{g} / \mathrm{ml}$; lane $5,2.5 \mu \mathrm{g} / \mathrm{ml}$; lane $6,1.25 \mu \mathrm{g} / \mathrm{ml}$; lane $7,0.625 \mu \mathrm{g} / \mathrm{ml} ;$ lane $8,0.31 \mu \mathrm{g} / \mathrm{ml} ; \mathrm{lane} 9$, 
(nucleotide 222) and ending at the TGA codon (nucleotide 1944), encoding for a 574 amino acid protein. This initiation ATG codon, a position +222 , is flanked by nucleotides which have a close homology to the Kozak's consensus sequence (Kozak, 1986a). The nucleotide sequence of rtER cDNA (Fig. 2) features a complete 3 ' non-coding region of $1324 \mathrm{bp}$ with a polyadenylation signal (AATAAA), 12 nucleotides upstream from the poly A tail. The CATTG sequence was found 10 bp upstream from the AATAAA, which was recognized by Benoist et al. (1980) and Berget (1984) to be adjacent to the polyadenylation site in several sequenced DNAs and to be a recognition element related to cleavage site selection. This sequence could be located either upstream or downstream from the polyadenylation signal (Berget, 1984). It may be pointed out that the $5^{\prime}$ end non-coding sequence has another short open reading frame starting at an ATG codon (nucleotide 17) and ending at a TAG codon (nucleotide 101) able to code for a 28 amino acid peptide. These short coding sequences upstream from the initiation codon are very often found in eukaryotic mRNA (Hunt, 1985; Kozak, 1986b) and also in ER mRNA

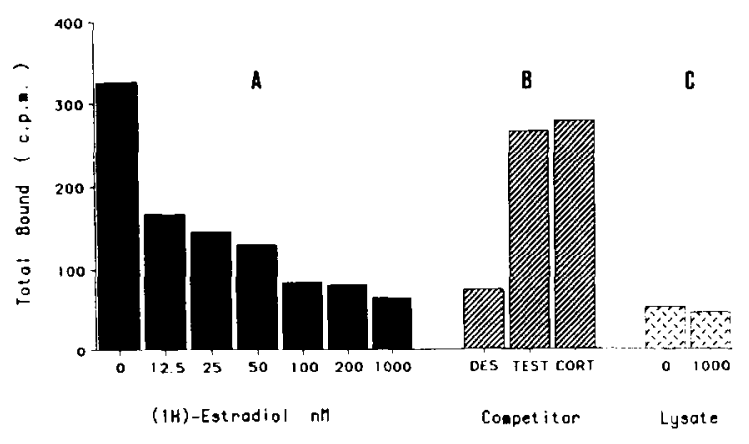

Fig. 4. Estradiol binding to in vitro translation products of rtER mRNA. $0.5 \mu \mathrm{g}$ of in vitro synthesized rtER mRNA was translated in rabbit reticulocyte lysate (final volume $50 \mu \mathrm{l}$ ). 25 $\mu l$ of the in vitro translation mix were incubated with $6 \mathrm{nM}$ $\left[{ }^{3} \mathrm{H}\right] \mathrm{E}_{2}$ either in the presence or absence of increasing concentrations of unlabeled estradiol $(A)$ and with $1 \mathrm{mM}$ of various competitors $(B)$. The non-specific binding was determined through incubation of lysate (without mRNA) with 6 $n M\left[{ }^{3} \mathrm{H}\right] \mathrm{E}_{2}$ either in the presence or absence of $1 \mathrm{mM}$ unlabeled estradiol $(C)$. Steroid competitors are diethylstilbestrol (DES), testosterone (TEST) and cortisol (CORT). The values represent the duplicate determination mean of the total bound of $\left[{ }^{3} \mathrm{H}\right] \mathrm{E}_{2}$. in different species (Green et al., 1986; Krust et al., 1986; White et al., 1987), but their function is still unknown.

We previously compared the sequence homologies between rtER and other ERs (Pakdel et al., 1988). The complete sequence confirms these homologies particularly in the $\mathrm{C}$ and $\mathrm{E}$ domains where we identified a cysteine 495 corresponding to the MCF-7 ER cysteine 530 (Harlow et al., 1989) which covalently binds the antiestrogen $\left[{ }^{3} \mathrm{H}\right]$ tamoxifen aziridine.

However, the most notable difference between rtER and other ERs is the lack of 37 amino acids specific to the A domain. This region, whose function remains unclear, is very well conserved between hER and cEK (87\%) and a bit less between hER and xER (60\%) (Krust et al., 1986; Weiler et al., 1987). The absence of this region gives rise to a smaller ER (574 amino acids, $63 \mathrm{kDa}$ ) in the rainbow trout as compared to other species.

In vitro expression of the full-length rtER cDNA and biological activity of the translation products

Translation product analysis. The full-length cDNA (3270 bp) containing the entire rtER coding region was inserted into the EcoRI site of expression vector Bluescript, in normal orientation. RNA transcript synthesized by $T_{7}$ RNA polymerase from this template migrates as a single band in 1\% agarose gel with a molecular weight identical to the native rtER mRNA (result not shown).

Both capped and uncapped mRNA were used to program protein synthesis in rabbit reticulocyte lysates and the $\left[{ }^{35} \mathrm{~S}\right]$ methionine-labeled products were separated on SDS-polyacrylamide gels. Fig. $3 A$ shows that the translation efficiency is not modified by the capping, contrary to the in vivo translations in Xenopus oocytes (Krieg and Melton, 1984). In all cases (lanes 2, 3 and 4) three major bands of approximately 63,61 and $44 \mathrm{kDa}$ may be observed. The $63 \mathrm{kDa}$ band probably represents the complete mRNA translation product, because its estimated molecular weight is similar to that of a 574 amino acid protein. The other bands can be generated through translation initiation at internal AUG codons, through proteolytic cleavage at specific sites or through incomplete translation. 

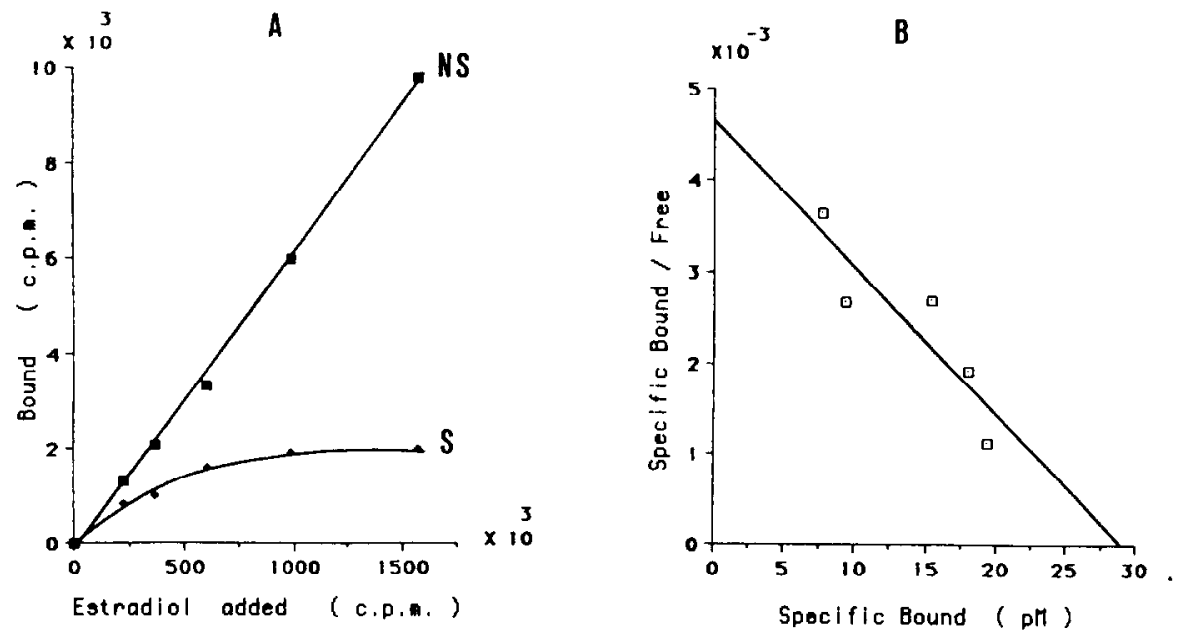

Fig. 5. Scatchard analysis of estradiol-binding to in vitro rtER translation products. $0.5 \mu \mathrm{g}$ of in vitro synthesized rtER $\mathrm{mRNA}$ was translated in rabbit reticulocyte lysate (final volume $50 \mu 1$ ). $20 \mu 1$ of the in vitro translation mix were incubated with increasing concentrations $(0.6-10 \mathrm{nM})$ of $\left[{ }^{125} \mathrm{I}\right] \mathrm{E}_{2}$ either in the absence or presence of a 100 -fold excess of unlabeled estradiol for $12 \mathrm{~h}$ at $2{ }^{\circ} \mathrm{C}$. At the end of the incubation period, total bound radioactivity (in assays without unlabeled $\mathrm{E}_{2}$ ) and non-specific bound radioactivity (in assays with unlabeled $\mathrm{E}_{2}$ ) were determined through the use of the DCC technique. $A$ : Saturation analysis of $\left[{ }^{125} \mathrm{I}\right] \mathrm{E}_{2}$ binding. $\mathrm{NS}$, non-specific binding; $\mathrm{S}$, specific binding. $B$ : Scatchard analysis of specific binding from $(A)$. The estimated dissociation constant $\left(K_{\mathrm{d}}\right)$ is about $5 \mathrm{nM}$.

Fig. $3 B$ shows electrophoretic analysis of the translation products whenever decreasing concentrations of rtER mRNA are used. The amount of translation products remains constant from 40 $\mu \mathrm{g} / \mathrm{ml}$ until $1.25 \mu \mathrm{g} / \mathrm{ml}$, then decreases between 625 and $150 \mathrm{ng} / \mathrm{ml}$ but remains detectable.

Analysis of estradiol $\left(E_{2}\right)$ binding with the translation products

Competition experiments. To test the biological properties of rtER translation products, aliquots were incubated with $6 \mathrm{nM}\left[{ }^{3} \mathrm{H}\right] \mathrm{E}_{2}$ either with or without unlabeled competitors.

Translation products do bind $\mathrm{E}_{2}$ specifically. Non-specific binding represents only $10-15 \%$ of total bound $\left[{ }^{3} \mathrm{H}\right] \mathrm{E}_{2}$ (Fig. 4A). A high concentration $(1 \mu \mathrm{M})$ of unlabeled $\mathrm{E}_{2}$ or diethylstilbestrol (DES) invariably competes with labeled $\mathrm{E}_{2}$ for specific binding, while testosterone or cortisol has a negligible effect (Fig. $4 B$ ).

Determination of the dissociation constant $\left(K_{d}\right)$. ${ }^{125}$ I-labeled estradiol was used for this experiment. Because its specific activity is 20 times higher than that of tritiated $E_{2}$, it allowed better binding

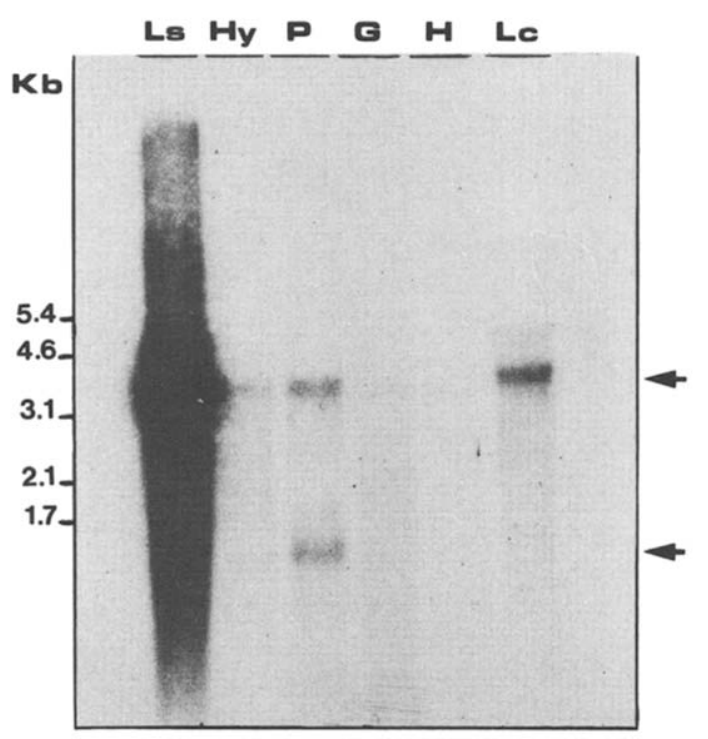

Fig. 6. Tissue distribution of $\mathrm{rtER}$ mRNA. $3 \mu \mathrm{g}$ of $\operatorname{poly}(\mathrm{A})^{+}$ mRNA, isolated from rainbow trout $\mathrm{E}_{2}$-stimulated liver (Ls), hypothalamus (Hy), pituitary (P), female gonads (G) and control liver (Lc), were separated on a denaturing formaldehyde agarose (1\%) gel, transferred to a nylon membrane, and then hybridized under Thomas's (1980) conditions with ${ }^{32} \mathrm{P}$-labeled complete rtER cDNA. 
estimations, especially for low estradiol concentrations. Incubations with increasing $\mathrm{E}_{2}$ concentrations showed saturability of specific sites (Fig. $5 A$ ), and the dissociation constant $\left(K_{\mathrm{d}} \approx 5 \mathrm{nM}\right.$ ) could be estimated by means of Scatchard graphical representation (Fig. 5B).

\section{Tissue distribution of rtER $\mathrm{mRNA}$}

In the oviparus species, estrogen's main target organs are the liver and the oviduct. In salmonids, there is no oviduct, so we tested for the presence of rtER mRNA in various other organs. Fulllength rtER cDNA was used for hybridization, under stringent conditions, of poly $(A)^{+}$RNA extracted from tissues.

Fig. 6 shows that a mRNA receptor $(3.5 \mathrm{~kb})$ of identical size can be detected in the pituitary and hypothalamus, but not in the heart nor in female gonads. ER mRNA concentration is higher in the liver, especially following $E_{2}$ stimulation. However, in the pituitary, a smaller sized mRNA (1.4 kb) also appears.

\section{Discussion}

The sequence homologies between rtER and other ERs have already been discussed (Pakdel et al., 1988). The present study gives further information about the high homology of domain $\mathrm{C}$ (92-95\%). At the 5'-end coding region of the rtER may be noticed the lack of 37 amino acids specific to the A domain, which is a very well conserved domain in other species $(87 \%$ between hER and cER, 60\% between hER and xER) (Krust et al., 1986; Weiler et al., 1987). This structure was confirmed hy genomic clone's sequences (I.P. le Pennec, personal communication). The function of this region is still unclear, but its high conservation level shows that it must be essential for the biological activity of the receptors. For instance it has been shown that portions of the $N$ terminal domains possess a transactivation function (Cato and Ponta, 1989); because of the absence of the A domain in the rtER, such a function, which would have occurred during the evolutionary process of the animal species might not exist in the rainbow trout or would be ensured by another peptide in this particular species. In any case, it would be of great interest to find out if this characteristic is specific to the whole fish class, salmonids being relatively primitive among teleost.

Comparison of 5' and $3^{\prime}$ non-coding sequences of the rtER cDNA with those of other species shows no significant homology. However, as in other ER mRNA (Green, 1986; Krust et al., 1986; White et al., 1987), on the one hand, we can notice at the $5^{\prime}$ end the presence of a small open reading frame coding a 28 amino acid peptide (these upstream minicistrons being usually present in cellular mRNAs not for their coding capacity but for regulatory purposes (Kozak 1986b)) and, on the other hand, at the $3^{\prime}$ end the presence of a long non-coding sequence which may play a role in mRNA stability (this region of the mRNAs containing possibly regulatory sequences such as the stretches of AT-rich sequences found in the untranslated portions of a number of transiently expressed mRNAs (Raghow, 1987)).

In vitro expression of the full-length rtER cDNA shows that the translation of our rtER mRNA in the rabbit reticulocyte lysate system is very efficient, since it is still detectable with 0.15 $\mu \mathrm{g} / \mathrm{ml}$ of translation mix. This concentration is about 200 times lower than the concentrations generally used for this type of experiment. However, it must be pointed out that the proportion of the different band remains constant when the concentration of mRNA is lowered, contrary to the recent findings of Dasso and Jackson (1989).

The binding experiments demonstrate that estrogens $\left(E_{2}\right.$ and DES) are bound by the translation products with a dissociation constant $(5 \mathrm{nM}$ for estradiol only), which is in keeping with the values previously found in vivo (Lazier et al., 1985; Maitre et al., 1985). Furthermore, binding sites are specific to estrogens. These findings confirm that our cDNA corresponds to a rainbow trout estrogen receptor $\mathrm{mRNA}$, and that specific post-translational modifications are not necessary to ensure binding activity.

Finally, the rtER mRNA was detected in the pituitary and hypothalamus. rtER mRNA is less abundant in these tissues than in the liver, but we suspect that ER gene expression does not concern all cell types of these tissues and we plan to localize the target cells through in situ hybridization. The rtER mRNA was not detected in the immature ovaries which are supposed to be estro- 
gen-sensitive tissues. Further experiments are needed to know if this is due to a lack of sensitivity or if the receptor is only expressed during some critical steps of ovaries maturation. The pattern of receptor transcripts shows tissue specificity. The $3.5 \mathrm{~kb}$ mRNA can always be detected, while the $4.5 \mathrm{~kb}$ one is observed only in the liver and the 1.4 $\mathrm{kb}$ one only in the pituitary. These messengers were detected through hybridization under stringent conditions, so they must have a high homology with rtER mRNA.

The length of the smaller pituitary messenger $(1.4 \mathrm{~kb})$ suggests that it probably encodes a part of the receptor. Truncated ER messengers have previously been described. A $1.8 \mathrm{~kb}$ progesterone receptor mRNA containing $A, B$ and a part of $C$ domains was detected in chicken oviducts. The biological function of this messenger is not yet known (Conneely et al., 1987). In mouse ovaries, Northern hybridization with an ER probe showed a $1.5 \mathrm{~kb}$ mRNA containing only a part of $E$ and the entire $F$ domains. This specific messenger of the ovary could be a steroid-binding protein involved in estrogen action (Hillier et al., 1989).

Regarding the $1.4 \mathrm{~kb}$ pituitary messenger, further hybridization studies, with DNA and hormone binding probes, will be necessary to characterize which parts of the above-mentioned remain in this truncated messenger.

\section{References}

Aufrey, C. and Rougeon, F. (1980) Eur. J. Biochem. 107, $303-314$

Benoist, C., O'Hare, K., Breathnach, R. and Chambon, P. (1980) Nucleic Acids Res. 8, 127-142.

Berget, S.M. (1984) Nature 309, 179-182.

Cato, A.C.B. and Ponta, H. (1989) Mol. Cell. Biol. 9, 53245330.

Chang, C. and Kokontis, J. (1988) Biochem. Biophys. Res. Commun. 155, 971-977.

Conneely, O.M., Dobson, A.D.W., Tsai, M.J., Beattie, W.G., Toft, D.O., Huckaby, C.S., Zaruki, T., Schrader, W.T. and O'Malley, B.W. (1987) Mol. Endocrinol. 1, 517-525.

Contreras, R., Cheroutre, H., Degrave, W. and Fiers, W. (1982) Nucleic Acids Res. 10, 6353-6362.

Dasso, M.C. and Jackson, R.J. (1989) Nucleic Acids Res. 17, $3129-3144$.

Giguere, V., Hollenberg, S.M., Rosenfeld, M.G. and Evans, R.M. (1986) Cell 46, 645-652.
Giguere, V., Ong, E.S., Segui, P. and Evans, R.M. (1987) Nature 330, 624-629.

Giguere, V., Yang, N., Segui, P. and Evans, R.M. (1988) Nature 331, 91-94.

Green, S. and Chambon, P. (1987) Nature 325, 75-78.

Green, S., Walter, P., Kumar, V., Krust, A., Bornert, J.M., Argos, P. and Chambon, P. (1986) Nature 320, 134-139.

Harlow, K.W., Katzenellenbogen, B.S., Greene, G.L., Smith, D.N, and Katzenellenbogen, J.A. (1989) in Ninth International Symposium of the Journal of Steroid Biochemistry.

Henikoff, S. (1984) Gene 28, 351-359.

Hillier, S.G., Saunders, P.T.K., White, R. and Parker, M.G. (1989) J. Mol. Endocrinol. 2, 39-45.

Hollenberg, S.M., Weinberger, C., Ong, E.S., Cerelli, G., Oro, A., Lebo, R., Thompson, E.B., Rosenfeld, M.G. and Evans, R.M. (1985) Nature 318, 635-641.

Hunt, T. (1985) Nature 316, 580-581.

Jeltsch, J.M., Krozowski, Z., Quirin-Stricker, C., Gronemeyer, H., Simpson, R.J., Garnier, J.M., Krust, A., Jacob, F and Chambon, P. (1986) Proc. Nati. Acad. Sci. U.S.A. 83, 5424-5428.

Kozak, M. (1986a) Cell 44, 283-292.

Kozak, M. (1986b) Cell 47, 481-483.

Krieg, P.A. and Melton, D.A. (1984) Nucleic Acids Res. 12, $7057-7070$.

Krust, A., Green, S. Argos, P., Kumar, V., Walter, P., Bornert, J.M. and Chambon, P. (1986) EMBO J. 5, 891-897.

Kumar, V., Green, S., Staub, A. and Chambon, P. (1986) EMBO J. 5, 2231-2236.

Kumar, V., Green, S., Stack, G., Berry, M., Jin, J.R, and Chambon, P. (1987) Cell 51, 941-951.

Laemmli, U.K. (1970) Nature 227, 680-685.

Lazier, C.B., Lonergan, K. and Mommsen, T.P. (1985) Endocrinology 57, 234-245.

Maitre, J.L.. Mercier, L.. Dolo, L. and Valotaire, Y. (1985) Biochimie 67, 215-225.

Maxwell, B.L., McDonnell, D.P., Conneely, O.M., Schultz, T.Z., Greene, G.L. and O'Malley, B.W. (1987) Mol. Endocrinol. 1, 25-35.

McDonnell, D.P., Mangelsdorf, D.J., Pick, J.W., Haussler, M.R. and O'Malley, B.W. (1987) 235, 1214-1217.

Miller, J., McLachlan, A.D. and Klug, A. (1985) EMBO J. 4, 1609-1614.

Pakdel, F., Le Guellec, C., Vaillant, C., Le Roux, M.G, and Valotaire, Y. (1988) Mol. Endocrinol. 3, 44-51.

Privalsky, M.L., Boucher, P., Koning, A and Judelson, C. (1988) Mol. Cell. Biol. 8, 4510-4517.

Raghow, R. (1987) Trends Biochem. Sci. 12, 358-360.

Sanger, F., Nicklen, S. and Coulson, A.R. (1977) Proc. Natl. Acad. Sci. U.S.A. 74, 5463-5467.

Thomas, P.S. (1980) Proc. Natl. Acad. Sci. U.S.A. 77, 52015205.

Weiler, I.J., Lew, D. and Shapiro, D.J. (1987) Mol. Endocrinol. 1, 355-361.

Weinberger, C., Thompson, C.C., Ong, E.S., Lebo, R., Gruol, D.J. and Evans, R.M. (1986) Nature 324, 641-646.

White, R., Lees, J.A., Needham, M., Ham, J. and Parker, M. (1987) Mol. Endocrinol. 1, 735-744. 